Chirurgia (2021) 116: 24-33

No. 1, January - February

Copyright@ Celsius

http://dx.doi.org/10.21614/chirurgia.116.1.24

\title{
Predictors of Survival among Early Onset Pancreatic Adenocarcinoma Patients A Tertiary Care Center Experience
}

\author{
Ahmad M. Alkashash', Maha AT Elsebaie ${ }^{2}$, Mohamed H. Bikhet ${ }^{3}$, Mahmoud Morsi ${ }^{3}$, Ravi K. Paluri ${ }^{4^{*}}$ \\ 'Department of Pathology, Indiana University, USA \\ 2Department of Internal Medicine, John H. Stroger Hospital of Cook County, Chicago, USA \\ ${ }^{3}$ Department of Surgery, University of Alabama in Birmingham, USA \\ ${ }^{4}$ Department of Hematology and Oncology, University of Alabama in Birmingham, USA
}

*Corresponding author:

Ravi Kumar Paluri MD, MPH. FACP

Assistant Professor

Division of Hematology Oncology

Associate Scientist, Experimental

Therapeutics Program

Comprehensive Cancer Center

University of Alabama at Birmingham

E-mail: rpaluri@uabmc.edu

\section{Rezumat}

Indici ai supraviețirii în rândul pacienților cu andenocarcinom pancreatic cu debut precoce. Experienta unui centru medical de specialitate

Obiective: Descrierea caracteristicilor clinice ale pacienților $\mathrm{cu}$ andenocarcinom pancreatic cu debut precoce şi analizarea factorilor prognostici care influențează supraviețuirea acestora.

Metode:Sinteza retrospectivă a 95 de pacienți, cu vârsta până în 45 de ani, inclusiv, care s-au prezentat la Spitalul Universitar din Alabama cu andenocarcinom pancreatic în perioada septembrie 1998-iunie 2018.

Rezultate:Durata medie de supraviețuire a fost de 12,9 luni pentru toți pacienții. Obezitatea, genul masculin, rasa şi localizarea tumorii nu au fost asociate cu supraviețirea. Fumatul în momentul stabilirii diagnosticului a determinat un risc de deces de trei ori mai mare (HR 3,05, IC 95\% 1,45-6,40). Riscul de deces a scăzut cu 64\% (HR 0,36, IC 95\% 0,16 - 0,78) în cazul pacienților care au suferit o intervenție chirurgicală. Durata medie de supraviețuire a fost de 119,5 luni pentru pacienții aflați în stadiul I, 29,9 luni pentru cei aflați în stadiul II, 23,23 luni pentru cei aflați în stadiul III şi 6,3 luni pentru cei aflați în stadiul IV. Efectul pozitiv al chimioterapiei asupra supraviețuirii a fost semnificativ doar în cazul asocierii cu FOLFIRINOX.

Concluzie: Anumiți factori prognostici care au fost stabiliți în cazul pacientilor $\mathrm{cu}$ andenocarcinom pancreatic tipic nu au caracter predictiv în ceea ce priveşte supraviețuirea în rândul 
pacienților tineri. Fumatul, un factor de risc cunoscut pentru apariția andenocarcinomului pancreatic cu debut precoce, este totodată un indiciu semnificativ al supraviețirii acestor pacienți. Eforturile de a îmbunătăți prognoza în cazul andenocarcinomului pancreatic cu debut precoce cuprind depistarea precoce, controlul tutunului, protocoalele de tratament personalizat şi studierea comportamentului biologic.

Cuvinte cheie: adenocarcinom pancreatic, debut precoce, fumat, supraviețuire, intervenție chirurgicală

\section{Abstract}

Objectives: To characterize clinical features of early onset pancreatic adenocarcinoma (EOPC) patients and explore prognostic factors affecting their survival.

Methods: Retrospective review of 95 patients, $\leq 45$ years old, who presented to the University of Alabama Hospitals with pancreatic adenocarcinoma from September 1998 to June 2018.

Results: Median survival time was 12.9 months for all patients. Obesity, male gender, race, and tumor location were not associated with survival. Smoking at time of diagnosis increased risk of death by three folds (HR 3.05, 95\% CI, 1.45 - 6.40). Risk of death decreased by 64\% (HR 0.36, 95\% CI, $0.16-0.78$ ) if patients underwent surgery. Median survival was 119.5 months for stage I, 29.9 months for stage II, 23.23 months for stage III, and 6.3 months for stage IV patients. The survival benefit of chemotherapy was only significant with the use of FOLFIRINOX.

Conclusion: Some established prognostic features in typical pancreatic adenocarcinoma patients are not predictive of survival in young patients. Cigarette smoking, a known risk factor for the development of EOPC, is also a significant predictor of survival in this patient population. Efforts to improve prognosis of EOPC include early detection, tobacco control, individualized treatment protocols, and studying the biological behavior.

Key words: pancreatic adenocarcinoma, early onset, smoking, survival, surgery

\section{Introduction}

Pancreatic cancer is the third most fatal cancer in the United States (1,2), with a 5-year overall survival (OS) rate less than $5 \%(1,3)$. Early onset pancreatic cancer (EOPC) is defined as pancreatic cancer diagnosed before the age of 50 years (4). Although EOPC represents only $5-10 \%$ of all pancreatic cancers, it is likely responsible for at least $30 \%$ of the total mortality burden of the disease $(4,5)$.

The effect of age at diagnosis on survival has been widely studied among patients with pancreatic adenocarcinoma (PAC). A study by Fadiel et al suggested better survival among early onset compared to late onset pancreatic adenocarcinoma (LOPC) patients (adjusted
HR: 0.82 , 95\% CI: 0.67-1.00), whereas a large analysis of the Surveillance, Epidemiology, and End Results database found that 5-year OS was worse among EOPC $(6,7)$. It is likely that variations in sample size, patient selection, and distribution of genetic/clinical risk factors among studied EOPC cohorts contributed to the observed discrepancies in survival outcomes. One observation remains consistent, however: EOPC likely represents a distinct clinical and biological entity than the typical LOPC population. Contemporary studies have also suggested genetic variations between EOPC and LOPC, such as lower rates of K-ras mutations and distinct single nucleotide polymorphisms among EOPC patients (8-10).

Differences in the pattern of survival 
between EOPC and LOPC patients imply different priorities for prevention and treatment among younger patients. Several risk factors have been suggested to increase the risk of developing PAC at an early age, including cigarette smoking, heavy alcohol consumption, and familial pancreatic cancer $(5,11,12)$. On the other hand, there is a scarcity of data on predictors of survival among EOPC patients. This hindered our ability to develop effective preventive measures and individualize treatment protocols. We believe there is a pressing need for studies examining prognostic features and clinical outcomes in EOPC patients. Therefore, we conducted a singlecenter, retrospective cohort study at the University of Alabama (UAB) Hospitals to characterize our 20-year institutional experience with early onset pancreatic adenocarcinoma.

\section{Methods}

\section{Aim}

1. Explore clinical features and tumor characteristics of EOPC patients.

2. Identify independent prognostic factors associated with survival of this patient population.

3. Investigate the role of different treatment modalities including different chemotherapeutic regimens in improving overall survival. The study was approved and a waiver of patient informed consent was granted by UAB Institutional Review Board.

\section{Patient Selection}

From our electronic medical record database (eEMR), we identified adult patients between the ages of 18 - 45 years old, with a histologically-proven diagnosis of pancreatic adenocarcinoma, who were managed at UAB between (September 1998 - June 2018).

\section{Data Extraction}

Patient data were extracted into pre-designed case report forms, then de-identified and anonymized prior to analysis. We collected information on: patient demographics, risk factors (e.g. smoking, alcohol consumption, history of pancreatitis), clinical presentation, tumor features including location within pancreas, histological subtype, evidence of lympho-vascular invasion, and treatment. We used the American Joint Committee on Cancer (AJCC) staging system - $7^{\text {th }}$ edition - to define clinical tumor stages (13). Overall survival was defined as the interval between the date of diagnosis till date of death from any cause or date of last follow-up.

\section{Statistical Analysis}

\section{Descriptive statistics}

Categorical variables are presented as frequencies and continuous variables are presented as mean + range, or median + standard deviation (SD). To compare the distribution of variables between patient subgroups, we used the $\chi^{2}$ tests for categorical variables and the Kruskal-Wallis test for continuous variables. A p-value $<0.05$ was considered significant.

\section{Survival probabilities}

Cumulative survival probabilities were estimated using the Kaplan-Meier method and compared using the log-rank test (14). All analyses were performed using Python v3.7.0 and IBM SPSS Statistics 26 (IBM Corp., Armonk, NY, USA). The cox proportionalhazards regression models were performed using the 'CoxPHFitter' function of Python's 'lifelines' 0.24.6 package.

\section{Cox regression models}

We estimated the hazard ratios (HRs) and 95\% confidence intervals (CIs). Each variable was adjusted to the following set of covariates: race, smoking, alcohol consumption, history of pancreatitis, clinical stage I, clinical stage II-III, and surgery. This set of covariates was chosen because of their clinical significance as predictors of survival and because these 
variables had the least amount of missing data. Variables could not be entered into the multivariable models for the following reasons: 1 . If they were explained by other covariates, raising convergence errors (e.g. clinical stage IV), or 2 . Due to missing information leading to a very small number of observed events in the model (e.g. tumor focality, tumor grade, and perineural invasion).

\section{Model accuracy assessment}

We used Harrell's Concordance Index (Cindex) to assess the regression models' accuracy and generalizability (15). C-index ranges between 50\% (random prediction) and 100\% (perfect concordance) between prediction and truth. We used two-fold cross validation and reported the mean testing $\mathrm{C}$-index. To obtain the final model parameters, we fit a new model to the entire patient cohort.

\section{Results}

\section{Patient and Tumor Characteristics}

eEMR search identified 109 potentially eligible patients. 14 patients were excluded because they were older than 45 years old $(\mathrm{N}=2)$, or because of lack of follow up information $(\mathrm{N}=$ 12). A total of 95 eligible patients were included in the study.

Patient characteristics including differences between patient who underwent or did not undergo surgery are summarized in Table 1 . $48.4 \%$ of the patients were males. The most common presenting symptoms were abdominal pain $(\mathrm{N}=59,62.1 \%)$, followed by obstructive jaundice $(\mathrm{N}=29,30.5 \%)$ and weight loss $(\mathrm{N}=18$, $18.9 \%)$. Primary tumor location was the head of pancreas in $56.8 \%$ of the patients. 42 patients $(44.2 \%)$ presented with metastatic disease. Metastatic sites were as follows: liver - 27 (28.4\%), lung - $6(6.3 \%)$, and other locations $10(10.5 \%)$.

\section{Treatment Overview}

38 patients $(40 \%)$ presented with potentially resectable disease, while $50(52.6 \%)$ underwent surgical resection. Of the patients whose disease was deemed unresectable during initial assessment but ended up undergoing surgery, 2 underwent Whipple resection and 2 underwent distal pancreatectomy. Details of surgery were missing for remaining patients.

Patients who underwent surgery were more likely to have tumors with defined gross morphology $(p<0.001)$, a localized stage I-II disease $(p<0.001)$, and resectable disease during initial assessment $(\mathrm{p}<0.001)$.

On the contrary, tumor location within the pancreas $(p=0.523)$ and number of tumor foci $(p=0.584)$ did not influence surgical decision (Table 1).

Margin status was available in 38 of the 50 patients $(76 \%)$ who underwent surgical resection; 32 patients $(64 \%)$ had an $\mathrm{R} 0$ resection and 6 patients (12\%) underwent $\mathrm{R} 1$ resection.

\section{Survival Outcomes}

The $1 \mathrm{y}, 2 \mathrm{y}$, and $5 \mathrm{y}$ OS rates were $55.2 \%, 38 \%$, and $22.3 \%$ respectively, with a median survival time of 12.9 months (95\% CI, 8.23 - 17.57) (Fig. 1). Increasing age, obesity, male gender, alcohol consumption, and personal history of diabetes or pancreatitis did not have a significant effect on overall survival. In contrast, current smokers at time of pancreatic cancer diagnosis had an adjusted HR for death of 3.05

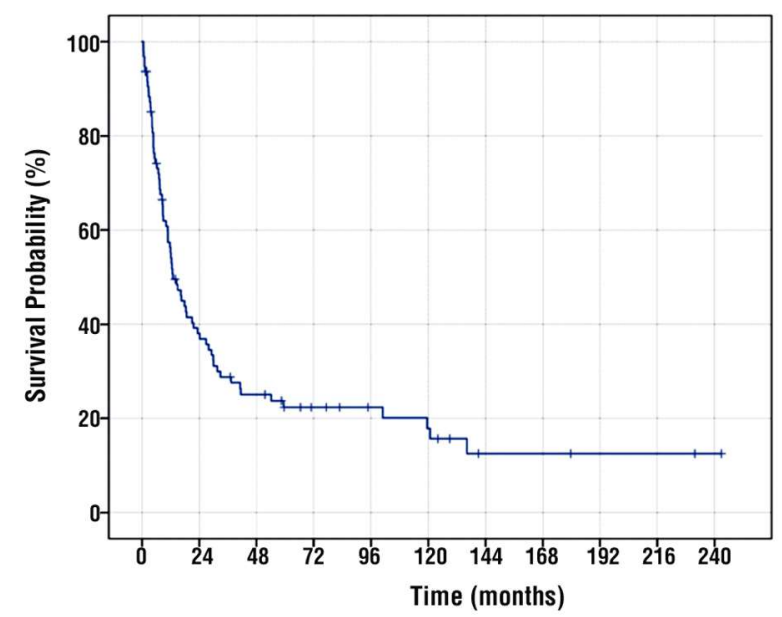

Figure 1. Kaplan-Meier overall survival probability in patients with Early Onset Pancreatic Cancer (EOPC) 
Table 1. Patient Characteristics and Distribution of Surgery

\begin{tabular}{|c|c|c|c|c|}
\hline Characteristic & $\begin{array}{c}\text { Total N. } \\
(\%)\end{array}$ & $\begin{array}{c}\text { Surgery } \\
(\mathrm{N}=\mathbf{5 0})\end{array}$ & $\begin{array}{c}\text { No Surgery } \\
(\mathrm{N}=45)\end{array}$ & $P$ value \\
\hline Age (yr), mean (range) & $40.78(20-45)$ & 40.12 & 41.51 & 0.468 \\
\hline Weight (kg), mean (range) & $77.1(45-113.4)$ & 73.7 & 84.1 & 0.046 \\
\hline Male & $46(48.4)$ & 22 & 24 & 0.414 \\
\hline White & $62(65.3)$ & 33 & 29 & 0.992 \\
\hline African American & $30(31.6)$ & 16 & 14 & 0.992 \\
\hline Smoking & $42(44.2)$ & 23 & 19 & 0.491 \\
\hline Alcohol consumption & $33(34.7)$ & 21 & 12 & 0.646 \\
\hline History of Pancreatitis & $20(21.1)$ & 14 & 6 & 0.299 \\
\hline History of Diabetes & $10(10.5)$ & 8 & 2 & 0.177 \\
\hline History of Cancer & $6(6.3)$ & 3 & 3 & 1.000 \\
\hline \multicolumn{5}{|l|}{ Gross tumor morphology } \\
\hline Defined tumor/ulcer & 60 (63.2) & 44 & 16 & \\
\hline Undefined & $34(35.8)$ & 5 & 29 & $<0.001$ \\
\hline \multicolumn{5}{|l|}{ Primary Tumor Location } \\
\hline Head of Pancreas & $54(56.8)$ & 29 & 25 & \\
\hline Body of Pancreas & $13(13.7)$ & 8 & 5 & \\
\hline Tail of Pancreas & $16(16.8)$ & 9 & 7 & \\
\hline Other location* & $12(12.6)$ & 4 & 8 & 0.523 \\
\hline \multicolumn{5}{|l|}{ Histological subtype } \\
\hline Ductal Adenocarcinoma & $5(5.3)$ & 4 & 1 & \\
\hline Signet-ring Cell carcinoma & $3(3.2)$ & 1 & 2 & \\
\hline Mucinous adenocarcinoma & $7(7.4)$ & 6 & 1 & \\
\hline Adenocarcinoma (NOS) & $70(73.7)$ & 31 & 39 & \\
\hline Other histology & $10(10.5)$ & 8 & 2 & 0.028 \\
\hline \multicolumn{5}{|l|}{ Clinical Stage } \\
\hline Stage I & $21(22.1)$ & 17 & 4 & \\
\hline Stage II & $19(20.0)$ & 18 & 1 & \\
\hline Stage III & $10(10.5)$ & 4 & 6 & \\
\hline Stage IV & $42(44.2)$ & 8 & 34 & $<0.001$ \\
\hline Lymphovascular invasion & $19(20)$ & 14 & 5 & 0.044 \\
\hline Perineural invasion & $12(12.6)$ & 12 & 0 & NA \\
\hline Peripancreatic extension & $14(14.7)$ & 14 & 0 & NA \\
\hline Invasion of adjacent organs & $9(9.5)$ & 9 & 0 & NA \\
\hline \multicolumn{5}{|l|}{ Tumor Grade } \\
\hline G1-G2: well-moderately differentiated & $18(18.9)$ & 18 & 0 & \\
\hline G3: poorly differentiated & $14(14.7)$ & 9 & 5 & 0.010 \\
\hline \multicolumn{5}{|l|}{ Resectability prior to treatment } \\
\hline Resectable & $38(40.0)$ & 37 & 1 & \\
\hline Unresectable & $48(50.5)$ & 10 & 38 & $<0.001$ \\
\hline \multicolumn{5}{|l|}{ Chemoradio modality } \\
\hline Adjuvant Chemo or Chemoradio & $12(12.6)$ & 10 & 2 & \\
\hline Neoadjuvant Chemo or Chemoradio & $9(9.5)$ & 7 & 2 & \\
\hline Palliative Systemic Chemotherapy & $27(28.4)$ & 3 & 24 & \\
\hline No Chemo or Chemoradio & $30(31.6)$ & 22 & 8 & $<0.001$ \\
\hline \multicolumn{5}{|l|}{ Chemotherapy regimen } \\
\hline FOLFIRINOX & $6(6.3)$ & 2 & 4 & \\
\hline Gemcitabine + Abraxane & $6(6.3)$ & 5 & 1 & \\
\hline Gemcitabine monotherapy & $7(7.4)$ & 5 & 2 & \\
\hline Other regimen** & $16(16.8)$ & 6 & 10 & \\
\hline No Chemotherapy & $13(13.7)$ & 12 & 1 & 0.008 \\
\hline
\end{tabular}


Table 2. Patient, Tumor And Treatment Related Characteristics Affecting Overall Survival (OS) Outcomes

\begin{tabular}{|c|c|c|c|c|c|c|}
\hline \multirow[t]{2}{*}{ Characteristics } & \multirow{2}{*}{$\begin{array}{r}\text { Univariable } \\
\text { P-value }\end{array}$} & \multicolumn{5}{|c|}{ Multivariable } \\
\hline & & $\begin{array}{l}\text { Total N. of } \\
\text { patients in } \\
\text { the model }\end{array}$ & HR & $95 \%$ Cl - LL & $95 \% \mathrm{Cl}-\mathrm{UL}$ & $\begin{array}{c}\text { Test } \\
\text { C-index }\end{array}$ \\
\hline Age (yr) & 0.159 & 71 & 1.00 & 0.94 & 1.07 & $64.0 \%$ \\
\hline Weight (kg) & 0.844 & 44 & 1.00 & 0.97 & 1.03 & $73.0 \%$ \\
\hline Gender (Male) & 0.377 & 71 & 0.99 & 0.53 & 1.87 & $74.6 \%$ \\
\hline Race (White) & 0.026 & 71 & 1.85 & 0.97 & 3.50 & $69.6 \%$ \\
\hline Smoking (Yes) & 0.004 & 71 & 3.05 & 1.45 & 6.40 & $69.6 \%$ \\
\hline Alcohol consumption (Yes) & 0.764 & 71 & 0.92 & 0.47 & 1.80 & $69.6 \%$ \\
\hline History of Pancreatitis (Yes) & 0.688 & 71 & 1.27 & 0.59 & 2.72 & $69.6 \%$ \\
\hline History of Diabetes (Yes) & 0.301 & 70 & 0.85 & 0.33 & 2.19 & $70.2 \%$ \\
\hline History of Cancer (Yes) & 0.135 & 71 & 1.21 & 0.45 & 3.25 & $75.7 \%$ \\
\hline Gross tumor morphology (Undefined) & 0.043 & 70 & 0.87 & 0.32 & 2.38 & $76.2 \%$ \\
\hline Tumor focality (multiple) & 0.247 & 55 & 0.79 & 0.17 & 3.76 & $73.1 \%$ \\
\hline \multicolumn{7}{|l|}{ Primary Tumor Location } \\
\hline Head of Pancreas & 0.266 & 71 & 0.90 & 0.49 & 1.65 & $72.9 \%$ \\
\hline Body of Pancreas & 0.140 & 71 & 1.27 & 0.49 & 3.24 & $74.2 \%$ \\
\hline Tail of Pancreas & 0.124 & 71 & 0.79 & 0.34 & 1.82 & $70.8 \%$ \\
\hline Other location* & 0.016 & 71 & 1.66 & 0.56 & 4.90 & $75.1 \%$ \\
\hline Histology [Adenocarcinoma (NOS)] & 0.023 & 71 & 0.83 & 0.39 & 1.78 & $74.0 \%$ \\
\hline Clinical N stage (N1) & $<0.001$ & 71 & 1.43 & 0.58 & 3.50 & $74.5 \%$ \\
\hline \multicolumn{7}{|l|}{ Clinical AJCC Stage } \\
\hline Stage I & $<0.001$ & 71 & 0.16 & 0.06 & 0.46 & $69.6 \%$ \\
\hline Stage II-III & 0.146 & 71 & 0.49 & 0.23 & 1.04 & $69.6 \%$ \\
\hline Stage IV & REF & REF & REF & REF & REF & REF \\
\hline Locally advanced (Yes) & 0.015 & 60 & 1.07 & 0.50 & 2.30 & $78.1 \%$ \\
\hline Lymphovascular invasion (Yes) & 0.309 & 39 & 1.21 & 0.45 & 3.24 & $70.6 \%$ \\
\hline Peri-neural invasion (Yes) & 0.886 & & & & & \\
\hline Peri-pancreatic extension (Yes) & 0.352 & & & & & \\
\hline Peri-nodal extension (Yes) & 0.016 & & & & & \\
\hline Invasion of adjacent organs (Yes) & 0.171 & & & & & \\
\hline $\begin{array}{l}\text { Tumor Grade: G1-G2 } \\
\text { (well-moderately differentiated) }\end{array}$ & 0.005 & & & & & \\
\hline Resectable prior to treatment (Yes) & $<0.001$ & 69 & 0.66 & 0.23 & 1.88 & $72.4 \%$ \\
\hline Surgery (Yes) & $<0.001$ & 71 & 0.36 & 0.16 & 0.78 & $69.6 \%$ \\
\hline \multicolumn{7}{|l|}{ Chemoradio modality } \\
\hline Adjuvant Chemo or Chemoradio & 0.800 & 64 & 1.32 & 0.42 & 4.20 & $73.6 \%$ \\
\hline Neo-adjuvant Chemo or Chemoradio & 0.087 & 64 & 0.43 & 0.14 & 1.38 & $76.1 \%$ \\
\hline Palliative Systemic Chemotherapy & $<0.001$ & 64 & 1.77 & 0.68 & 4.60 & $69.6 \%$ \\
\hline No Chemo or Chemoradio & 0.019 & 64 & 0.90 & 0.32 & 2.51 & $74.5 \%$ \\
\hline \multicolumn{7}{|l|}{ Chemotherapy Regimen } \\
\hline FOLFIRINOX & 0.231 & 45 & 0.17 & 0.04 & 0.78 & $75.9 \%$ \\
\hline Gemcitabine + Abraxane & 0.020 & 45 & 2.38 & 0.71 & 7.90 & $66.8 \%$ \\
\hline Gemcitabine monotherapy & 0.262 & 45 & 2.34 & 0.78 & 7.04 & $67.3 \%$ \\
\hline Other regimen** & 0.087 & 45 & 1.70 & 0.71 & 4.10 & $66.1 \%$ \\
\hline No Chemotherapy & 0.007 & 45 & 0.27 & 0.06 & 1.26 & $66.0 \%$ \\
\hline
\end{tabular}

HR: Hazard ratio, Cl: Confidence interval, LL: Lower limit, UL: Upper limit. Bold = Significant values.

${ }^{*}$ Other locations included: Uncinate process, overlapping pancreatic regions, and colo-rectal. NOS: Not otherwise specified. Chemoradio: Chemotherapy-radiotherapy, Chemo: Chemotherapy. ${ }^{* *}$ Other regimens included Gemcitabine + Oxaliplatin, Gemcitabine + Docetaxel, and Taxotere monotherapy among others. Empty rows correspond to covariates that were not entered into the multivariate models because they were either explained by other covariates or did not meet the model inclusion criteria (due to small number of events or other reasons - see Methodology section for details). 


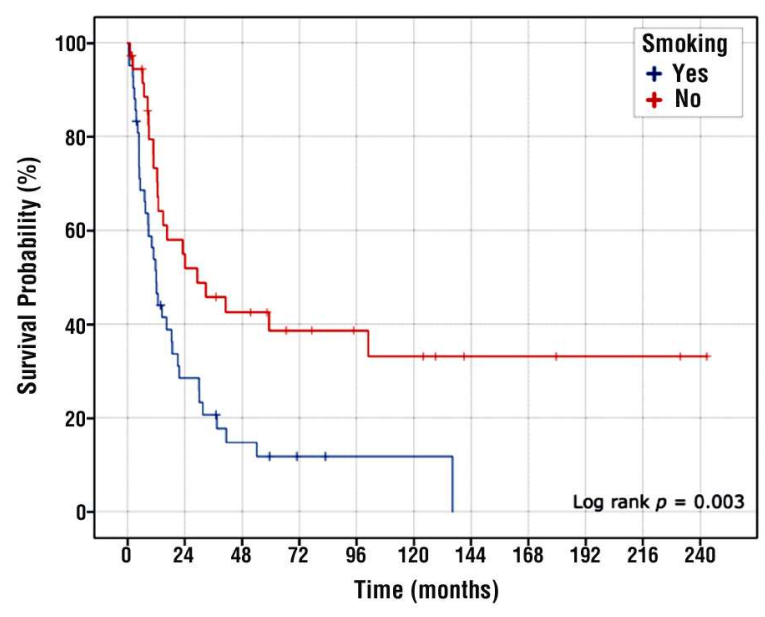

Figure 2. Kaplan-Meier overall survival probability by history of smoking

$(95 \%$ CI, $1.45-6.40$, C-index $=69.6 \%)$ compared with nonsmokers (Table 2, Fig. 2). This effect of smoking was independent of patient age, gender, race, alcohol use, and body weight, history of diabetes or pancreatitis. It was also not modified by tumor stage or therapy in the multivariable models.

African American patients had a median survival of 31.5 month (95\% CI, 6.6- 56.5). Patients of white ethnicity had a median survival of 12.06 month (95\% CI, 9.9- 14.1). This racial disparity had no statistically significant effect on overall survival of our EOPC cohort (HR 1.85, 95\% CI, 0.97- 3.50, C-index $=69.6 \%)$.

Clinical stage specific median survival was 119.5 months (95\% CI, 0.57 - 254.3) for stage I, 29.9 months (95\% CI, 25.98 - 33.82) for stage II, 23.23 months (95\% CI, 7.43 - 39.03) for stage III, and 6.3 months (95\% CI, 3.41 - 9.19) for stage IV (Fig. 3). Risk of death decreased by $64 \%$ if patients underwent surgery (Table 2 ). Median survival time was 31.6 months, $(95 \% \mathrm{CI}$ 17.6 - 45.5) in patients who underwent surgery compared to 7.4 months, (95\%CI 5.6 9.2) in those who did not.

Forty-eight patients $(50.5 \%)$ in our cohort received chemotherapy. Information on chemotherapy regimens were available in 35 of these 48 patients $(36.8 \%)$. The survival benefit of

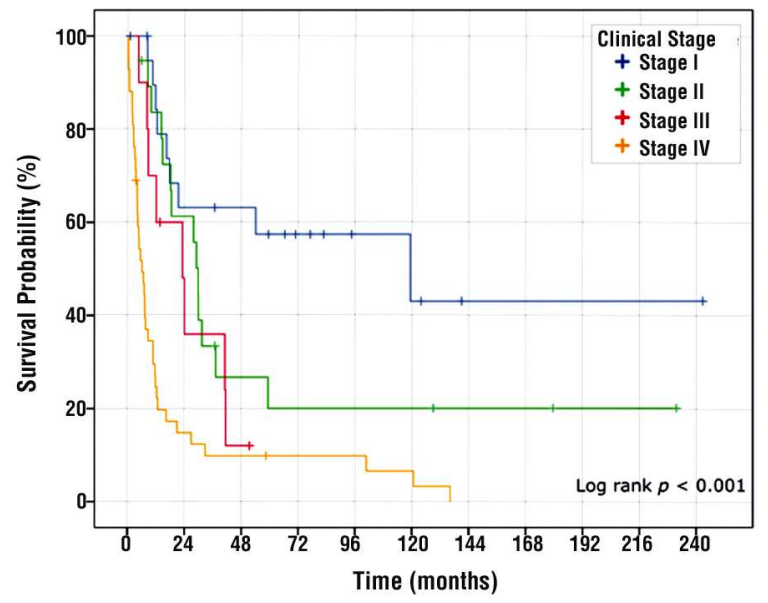

Figure 3. Kaplan-Meier overall survival probability by the American Joint Committee on Cancer (AJCC) clinical stage

chemotherapy was statistically significant only with the use of FOLFIRINOX compared to the other chemotherapy regimens (HR $0.17,95 \% \mathrm{CI}$ $0.04-0.78$, C-index $=75.9 \%)$. This finding should be regarded with caution, since the number of patients with FOLFIRINOX regimen was only 6 patients in our study.

\section{Discussion}

Less than $10 \%$ of patients diagnosed with PAC are under the age of 45 years at diagnosis, while the vast majority are diagnosed at median age of 72 (16). The poor survival of PAC doesn't seem to differ significantly in young patients compared to the typical older patient population. In contemporary cohort studies, the median survival of EOPC patients ranged between 5.7 - 19 month (16, 17 ), whereas the expected median survival in a typical PAC patient is around 8 months $(7,18,19)$. In our study, the median survival for the entire cohort was 12.9 months.

Our findings suggest that cigarette smoking is not only an important risk factor for the development of PAC at an earlier age, but is also a significant predictor of survival in this patient population $(20,21)$. In our cohort, $44.2 \%$ of patients had a significant smoking history, and cigarette smoking at 
time of pancreatic cancer diagnosis increased risk of death by 3 -fold.

So far, the association between cigarette smoking and pancreatic cancer survival has only been studied in a few observational studies and a handful of prospective cohorts $(22,23)$. In a recent systematic review and meta-analysis, current smokers had a $56 \%$ higher risk of mortality from pancreatic cancer than never smokers (23). Similarly, in a pooled analysis of 1,037 PAC patients from two large prospective cohorts, cigarette smoking was associated with a $37 \%$ increase in risk of death $(\mathrm{HR}=1.7,95 \% \mathrm{CI}, 1.11$ - 1.69) (24). A notable limitation of the aforementioned studies was: the mean age of PAC patients was between $67-72.7$ years old, and there were no subgroup analyses for young patients.

In a recent study of EOPC, the authors reported an increase in EOPC mortality in regions with high smoking prevalence rates (e.g. Central/Eastern European countries). In these regions, death from EOPC represented at least $30 \%$ of the total mortality burden of pancreatic cancer (5). Our study reinforces the observation that young, current smokers who are diagnosed with pancreatic cancer are at a significantly higher risk of death compared to non-smokers. Furthermore, the effect of smoking was not modified by tumor stage or therapy in our multivariable models. Tobacco control and smoking cessation can, therefore, have a profound effect on the survival of young patients with PAC. This is especially important in underdeveloped regions where smoking prevalence is higher and access to early diagnosis and care is lower (25).

Male sex, black ethnicity, and non-pancreatic head tumor location are among the most widely known adverse prognostic features in the typical PAC patient population (19). None of these features were associated with survival of our EOPC cohort. Similarly, in a multivariable survival analysis that included $>100$ EOPC patients, Fadiel et al found no association between race and overall survival (6). On the other hand, a report by the National Cancer Institute indicated that black patients, with pancreatic adenocarcinoma, between the ages of 30-54 years old had 50\% higher incidence and mortality rates compared to their white counterparts (26). The notable differences in median survival between black and white patients may be explained by variables like patient selection and genetics. These variables were beyond what we were able to obtain from retrospective chart review and were not adjusted for in the multivariable models. We believe that the association between race and survival of EOPC patients represents a clinically interesting point to follow.

Early detection may be the key to decreasing mortality from pancreatic cancer. The reported frequency of Stage I-II disease in EOPC patients ranges between $22-40 \%(6,4,7,16,18)$. We report a similar, yet slightly higher frequency of Stage I-II disease $(\sim 42 \%)$. This could be explained by the fact that most of our patients had symptomatic rather than silent disease and that most tumors lied within head of pancreas. Indeed, tumors of the pancreatic head/tail have a tendency to present late and often attain a large size before they produce clinical symptoms.

Unfortunately, in many population- and institution-based studies, at least $40-60 \%$ of EOPC patients presented with stage IV disease $(4,7,16,18)$. The majority of our cohort (> 44\%) presented with metastatic disease, and had a median survival of 6.3 months $(95 \%$ CI, 3.41 - 9.19). This dismal survival is similar to what would be expected in a typical older patient with metastatic PAC, and is also close to the total median survival of late onset PAC $(16,18,19)$. On the other hand, EOPC patients with non-metastatic disease seem to fare significantly better compared to their counterparts from the older PAC population.

The expected survival in typical older patients with PAC is $20 \pm 2$ months for stages I-II and $13.5 \pm 5$ months for stage III. Our data suggests an improved survival up to 119.5 months (95\% CI, 0.57 - 254.3) for stage I, 29.9 months (95\% CI, 25.98 - 33.82) for stage II, and 23.23 months (95\% CI, 7.43 - 39.03) for stage III patients. The survival of our EOPC patients with stage II-III disease compares 
favorably with other contemporary studies $(16,18,27)$. The most striking, however, was the survival of our stage I patients which seemed better than expected.

This improved survival can be explained in part - by the fact that the majority of our stage I patients underwent surgical resection with curative intent. Comparatively, the median survival of the unresected stage I patients in our cohort was significantly lower (12.7 months, 95\%CI $3.6-21.7, \mathrm{p}=0.046$ ). In a similar vein, a study by Memorial SloanKettering Cancer Center reported a significantly higher median survival (41.8 months, 95\% CI 20.3-47) for their 35 patients with stage I-II disease, who underwent curative resection, as compared with a median survival of 15.3 months (95\% CI 12-19.3) for those who presented with locally advanced, unresectable disease 16. Others have also reported better survival outcomes in operated EOPC patients as compared to their older counterparts $(28,29)$

We believe that a combination of factors including early disease stage, surgical resection, and younger age -with the lack of comorbidities and better tolerance to therapy- have contributed to the improved survival of young patients with early stage pancreatic adenocarcinoma in our as well as other cohorts. It remains unknown, however, if other biological factors inherent to the early stage EOPC are also playing a role.

\section{Limitations}

In this study, we presented our 20-year experience with the presentation and treatment of EOPC. The retrospective nature of this study limited our ability to address some of the possible biological predictors of survival, such as underlying genetic mutations. Genomic tumor profiling was uncommon before 2005, hence, this information was missing for the majority of our patients. Our analysis of risk factors, especially intensity of smoking and alcohol use, was limited by missing data and inconsistent documentation in patient charts.
Likewise, we had to use weight instead of BMI to assess the impact of obesity on patients' survival because of missing information on height in $\sim 60 \%$ of records we extracted. Finally, our study represents a single tertiary care center experience, and may overrepresent the number of patients suitable for surgery. Conducting a multi-center collaborative study can produce a more representative sample of the EOPC patient population, and is currently underway at our center.

\section{Conclusion}

In summary, pancreatic adenocarcinoma seems to behave differently in young patients compared to the typical older PAC patient population. Factors like gender, race, and tumor location have not been shown to predict survival in EOPC patients. In contrast, tobacco control and smoking cessation can improve prognosis of young patients with PAC. Early detection may be the key to decreasing mortality from EOPC. Patients with early disease stages have better prognosis and higher chances of undergoing surgery, which improve their prognosis even further. Future research is encouraged to 1) identify which young patients are at risk for pancreatic cancer, 2) characterize which young patients are at higher risk of death from pancreatic cancer, and 3) develop early detection methods, including potential biomarkers and enhanced imaging techniques.

\section{Funding}

The authors have not received any funding for this work.

Acknowledgements: None.

\section{Availability of Data and Materials}

The datasets used and analyzed during the current study are available from the corresponding author on reasonable request. 


\section{Conflict of Interest}

The authors report no conflict of interest concerning the materials or methods used in this study or the findings specified in this paper.

\section{Ethics of Approval}

The study was approved and a waiver of patient informed consent was granted by UAB Institutional Review Board.

\section{References}

1. Jemal $A$, Siegel $R$, Ward $E$, Hao $Y, X u$ J, Murray $T$, et al. Cancer statistics, 2008. CA Cancer J Clin. 2008;58(2):71-96.

2. Hidalgo M. Pancreatic cancer. N Engl J Med. 2010;362(17):1605-17.

3. Li D, Xie K, Wolff R, Abbruzzese JL. Pancreatic cancer. Lancet. 2004;363(9414):1049-57.

4. Bunduc S, lacob R, Costache R, Stoica B, Radu C, Gheorghe C. Very Early Onset Pancreatic Adenocarcinoma - Clinical Presentation, Risk Factors and Therapeutic Options. Chirurgia (Bucur). 2018;113(3):405-11.

5. Raimondi S, Maisonneuve P, Lohr JM, Lowenfels AB. Early onset pancreatic cancer: evidence of a major role for smoking and genetic factors. Cancer Epidemiol Biomarkers Prev. 2007;16(9): 1894-7.

6. Beeghly-Fadiel A, Luu HN, Du L, Shi C, McGavic DP, Parikh AA, et al. Early onset pancreatic malignancies: Clinical characteristics and survival associations. Int J Cancer. 2016;139(10):2169-77.

7. Ansari D, Althini C, Ohlsson H, Andersson R. Early-onset pancreatic cancer: a population-based study using the SEER registry. Langenbecks Arch Surg. 2019;404(5):565-71.

8. Bergmann F, Aulmann S, Wente MN, Penzel R, Esposito I, Kleeff J, et al. Molecular characterisation of pancreatic ductal adenocarcinoma in patients under 40. J Clin Pathol. 2006:59(6):580-4

9. Luttges J, Stigge C, Pacena M, Kloppel G. Rare ductal adenocarcinoma of the pancreas in patients younger than age 40 years. Cancer. 2004;100(1):173-82.

10. Chen J, Wu X, Huang Y, Chen W, Brand RE, Killary AM, et al. Identification of genetic variants predictive of early onset pancreatic cancer through a population science analysis of functional genomic datasets. Oncotarget. 2016;7(35):56480-90.

11. Piciucchi M, Capurso G, Valente R, Larghi A, Archibugi L, Signoretti $\mathrm{M}$, et al. Early onset pancreatic cancer: risk factors, presentation and outcome. Pancreatology. 2015;15(2):151-5.

12. McWilliams RR, Maisonneuve P, Bamlet WR, Petersen GM, Li D, Risch HA, et al. Risk Factors for Early-Onset and Very-Early-Onset Pancreatic Adenocarcinoma: A Pancreatic Cancer Case-Control Consortium (PanC4) Analysis. Pancreas. 2016; 45(2):311-6.

13. Edge SB, Compton CC. The American Joint Committee on Cancer: the $7^{\text {th }}$ edition of the AJCC cancer staging manual and the future of
TNM. Ann Surg Oncol. 2010;17(6):1471-4.

14. Kaplan EL, Meier P. Nonparametric Estimation from Incomplete Observations. J Am Stat Assoc. 1958;53(282):457-481.

15. Harald Steck and Balaji Krishnapuram and Cary Dehing-oberije and Philippe Lambin and Raykar VC. Advances in Neural Information Processing Systems 20 (ed J C Platt and D Koller and Y Singer and S T Roweis). 1209-1216 (Curran Associates, Inc., 2008).

16. Duffy A, Capanu M, Allen P, Kurtz R, Olson SH, Ludwig E, et al. Pancreatic adenocarcinoma in a young patient population--12-year experience at Memorial Sloan Kettering Cancer Center. J Surg Oncol. 2009;100(1):8-12.

17. Tingstedt B, Weitkamper C, Andersson R. Early onset pancreatic cancer: a controlled trial. Ann Gastroenterol. 2011;24(3):206-12.

18. Ntala C, Debernardi S, Feakins RM, Crnogorac-Jurcevic T. Demographic, clinical, and pathological features of early onset pancreatic cancer patients. BMC Gastroenterol. 2018;18(1):139.

19. Ordonez JE, Hester CA, Zhu H, Augustine M, Porembka MR, Wang SC, et al. Clinicopathologic Features and Outcomes of Early-Onset Pancreatic Adenocarcinoma in the United States. Ann Surg Oncol. 2020;27(6):1997-2006.

20. Brand RE, Greer JB, Zolotarevsky E, Brand R, Du H, Simeone D, et al. Pancreatic cancer patients who smoke and drink are diagnosed at younger ages. Clin Gastroenterol Hepatol. 2009;7(9):1007-12.

21. Lynch SM, Vrieling A, Lubin JH, Kraft P, Mendelsohn JB, Hartge P, et al. Cigarette smoking and pancreatic cancer: a pooled analysis from the pancreatic cancer cohort consortium. Am J Epidemiol. 2009;170(4):403-13.

22. Arnold LD, Patel AV, Yan Y, Jacobs EJ, Thun MJ, Calle EE, et al. Are racial disparities in pancreatic cancer explained by smoking and overweight/obesity? Cancer Epidemiol Biomarkers Prev. 2009; 18(9):2397-405.

23. Ben QW, Liu J, Sun YW, Wang LF, Zou DW, Yuan YZ. Cigarette Smoking and Mortality in Patients With Pancreatic Cancer: A Systematic Review and Meta-analysis. Pancreas. 2019;48(8):985-95.

24. Yuan C, Morales-Oyarvide V, Babic A, Clish CB, Kraft P, Bao Y, et al. Cigarette Smoking and Pancreatic Cancer Survival. J Clin Oncol. 2017;35(16):1822-8

25. Rawla P, Sunkara T, Gaduputi V. Epidemiology of Pancreatic Cancer: Global Trends, Etiology and Risk Factors. World J Oncol. 2019;10(1):10-27.

26. Miller BA, Kolonel LN, Bernstein L, Young, Jr. JL, Swanson GM, West D, Key CR, Liff JM, Glover CS, Alexander GA, et al. Racial/ Ethnic Patterns of Cancer in the United States 1988-1992, National Cancer Institute. Bethesda, MD, 1996. NIH Pub. 1996;NNo. 96-4104. Bethesda, MD, 1996. Available from: https://seer.cancer.gov/ archive/publications/ethnicity/racial-ethnic-monograph.pdf

27. Raissouni S, Rais G, Mrabti H, Raissouni F, Mouzount H, Aitelhaj M, et al. Pancreatic adenocarcinoma in young adults in a moroccan population. J Gastrointest Cancer. 2012;43(4):607-11.

28. He J, Edil BH, Cameron JL, Schulick RD, Hruban RH, Herman JM, et al. Young patients undergoing resection of pancreatic cancer fare better than their older counterparts. J Gastrointest Surg. 2013; 17(2):339-44

29. Lin JC, Chan DC, Chen PJ, Chu HC, Chueh TH, Huang HH, et al. Clinical characteristics of early onset pancreatic adenocarcinoma: a medical center experience and review of the literature. Pancreas. 2011;40(4):638-9. 